Article

\title{
Economic, Environmental and Energetic Analysis of a Distributed Generation System Composed by Waste Gasification and Photovoltaic Panels
}

\author{
Alvaro Quiles Garcia, Naoya Nishiumi *, Atsushi Saito, Eriko Matsumura * and Jiro Senda *
}

check for

updates

Citation: Garcia, A.Q.; Nishiumi, N.; Saito, A.; Matsumura, E.; Senda, J. Economic, Environmental and Energetic Analysis of a Distributed Generation System Composed by Waste Gasification and Photovoltaic Panels. Energies 2021, 14, 3889. https://doi.org/10.3390/en14133889

Academic Editor: Fernando

Rubiera González

Received: 21 April 2021

Accepted: 23 June 2021

Published: 28 June 2021

Publisher's Note: MDPI stays neutral with regard to jurisdictional claims in published maps and institutional affiliations.

Copyright: (c) 2021 by the authors. Licensee MDPI, Basel, Switzerland. This article is an open access article distributed under the terms and conditions of the Creative Commons Attribution (CC BY) license (https:// creativecommons.org/licenses/by/ $4.0 /)$.
Spray and Combustion Science Laboratory, Doshisha University, 1-3 Tataramiyakodani, Kyotanabe City 610-0321, Japan; alvaroquiles95@hotmail.com (A.Q.G.); a-saito@toyosekkei.co.jp (A.S.)

* Correspondence: ctwf0554@mail4.doshisha.ac.jp (N.N.); ematsumu@mail.doshisha.ac.jp (E.M.); jsenda@mail.doshisha.ac.jp (J.S.)

\begin{abstract}
Fossil fuel dependency in developed countries is worrisome due to the lack of energy security that traditional energy generation provides. In order to prevent future energy problems and to maintain a sustainable society, some countries are starting to develop renewable energy sources. In this research, biomass energy is introduced as a solution not only to reduce fossil fuel dependency, but also to improve municipal solid waste management. The purpose of this report is to construct a distributed power generation system combining the superheated steam gasification of solid waste and photovoltaic panels, and to verify the feasibility of generating power at the consumption site. It also focuses on optimizing the current waste superheated steam gasification system and compares the superheated steam gasification technology with other waste to energy technologies, such as downdraft air gasification and solid waste direct combustion. Finally, the report analyzes the economic, environmental and energetic viability of the above mentioned distributed generation system, which is located in a medium size mall surrounded by a community of 20,000 inhabitants. As a result, it was found that a distributed generation system composed by waste superheated steam gasification and photovoltaic panels is perfectly feasible, since its long term economic performance shows high profitability.
\end{abstract}

Keywords: distributed generation system; biomass; gasification; photovoltaic panels

\section{Introduction}

\subsection{Energy Generation Background}

Sustainability can be defined as the quality of causing no damage to the environment or society over a continued period of time. It is well known that the majority of developed countries have a huge dependency on fossil fuels, a clear example is Japan whose energy mix is composed of $42 \%$ liquefied natural gas (LNG), 31\% coal and $9 \%$ oil. As the worldwide population is increasing, consumption of fossil fuels continues to rise. Many developed countries have promoted global environmental concerns in terms of global warming, carbon dioxide emissions and sustainability. Furthermore, the current energy scope is threatened due to the expected increment in energy demand over the short term, and due to resources constraints such as the limitation of fossil fuels. In order to avoid a future problem in energy security and sustainability, it is necessary to develop new energy generation alternatives such as renewable energy approaches [1]. Renewable energies would increase the energy security and sustainability of the current energy scope by reducing fossil fuel dependency and, consequently, the amount of pollutants generated [2].

In this paper, waste gasification is introduced; the main goal of gasification systems is to transform municipal solid waste (MSW) into a high calorific gas called syngas. This high calorific gas can be later used as fuel for efficient energy generators, in contrast to output gases from traditional biomass combustion which must be burned directly due to the 
large amount of impurities contained. The main advantages of biomass energy generation systems are their versatile composition, availability, flexibility, and easy conversion into a wide range of products. Their main drawback is the production of $\mathrm{CO}_{2}$ emissions, which means that waste gasification is not considered a fully renewable technology.

Porteus (2005) studied the importance of avoiding traditional energy generation from fossil fuels and concluded two main arguments. First, the necessity of lowering the $\mathrm{CO}_{2}$ emissions currently produced by the energy generation industry, and second, the advantages of using municipal solid waste as a biomass resource. By using waste to energy methods, there is the saving of an estimated $270 \mathrm{~kg}$ of equivalent $\mathrm{CO}_{2}$ per each ton of waste gasified rather than landfilled [3]. Following this research, Arena (2012) affirmed that by using city waste as a biomass resource, waste in volume is reduced by $80-90 \%$; this clearly improves the current scope of waste management in big cities and reduces emissions of $\mathrm{CO}_{2}$ and other greenhouse gases [4]. Consonni and Vigano (2012) concluded that by using waste to energy plants, landfilling is highly reduced because the municipal waste generated is used as biomass fuel, in contrast with traditional energy generation systems where municipal solid waste is not used in the process and, therefore, it is necessary to landfill it [5].

In this research, waste gasification is proposed as a biomass energy generation system; its main goal is to transform MSW into a high calorific gas, syngas. This high calorific gas can be later used as fuel for efficient energy generators, in contrast to output gases from biomass combustion which must be directly burned due to the large amount of impurities they contain.

Gasification has plenty of benefits compared with biomass combustion: (i) gasification gas output (i.e., syngas) is much easier to control and burn than solid waste, which leads to a higher efficiency; (ii) the range of scale is huge, although the best option is small scale plants in terms of efficiency; (iii) by using gasification, the amount of pollutants generated is greatly decreased; (iv) the syngas produced can be used to generate high quality fuels or chemicals; (iv) the possibility to recycle and improve the quality of solid metal residues $[4,6]$.

On the other hand, there are some drawbacks of gasification techniques that are worth mentioning: (i) syngas is a toxic and explosive gas; (ii) although emissions are lower, NOx emissions are quite high; (iii) plants are more complex, because two stages are needed to generate energy, the first one to create syngas and the second to generate energy from the exhaust gas; (iv) both process and maintenance are more expensive and complex than biomass combustion [4,6].

The other renewable energy proposed in this paper consists of photovoltaic (PV) solar energy. Solar photovoltaic is a technique that converts solar radiation into direct current electricity by the usage of semiconductor materials. These semiconductor materials are placed within a PV cell, where electrons are free and form electric currents. Solar radiation is received worldwide with sufficient intensity levels to produce electricity in almost every place of our planet, depending on the specific latitude. PV solar energy generation has some important advantages, such as its low initial investment, since the PV panels can be placed at rooftops of buildings which are already constructed, and its high efficiency, making this renewable energy technique suitable for local generation. The main drawback is the intermittency and the unpredictability of solar radiation.

\subsection{Local Energy Generation}

Access to energy is an essential right and a priority for human society. During the last decades, energy has been generated in large scale power plants and distributed by the main power network, providing extremely low costs. This system is effective in populated regions, even though it has large energy transmission losses due to the large distance between generation and consumption points. This research studies the concept of local production for local consumption. 
There are many reasons to choose local energy generation: (i) local energy provides energy security; (ii) it builds infrastructure and increases outputs; (iii) it increases the efficiency of the energy system; (iv) it lowers the carbon footprint due to the reduction of transportation distances; (v) it also fights against poverty by creating jobs in local communities; (vi) finally, local energy ensures a fair price for undeveloped regions. Therefore, in order to preserve economic, social and environmental sustainability, as well as create a stronger and more resilient energy power system, it is recommendable to evolve into local energy systems [7].

A great solution for local energy generation could be the usage of distributed generation systems (DGS), which are smart micro grids composed of different energy techniques, with an on site consumption. The goal of this paper is to create a DGS composed of biomass, solar and fossil fuel energies to cover the energy demand of a fictitious community. By applying this concept, it could be possible to construct a recycling society with extremely low energy losses, low $\mathrm{CO}_{2}$ emissions, and an effective waste management system, which could be a great solution to deal with future energy problems.

\subsection{Purpose of the Research}

The present research is based on the concept shown in Figure 1. Energy resources are divided into arterial resources (e.g., fossil fuels, food, water) and venous resources (e.g., organic waste, paper waste, plastic waste, vegetation waste, excrement waste). The energy system is also divided into an arterial energy system (e.g., thermal plants, hydraulic plants, gas plants, nuclear plants) and a venous energy system (e.g., renewable energy facilities). Current energy systems are worrisome due to their high dependency on the arterial system, since the majority of the energy used in developed countries comes from fossil fuels or nuclear power.

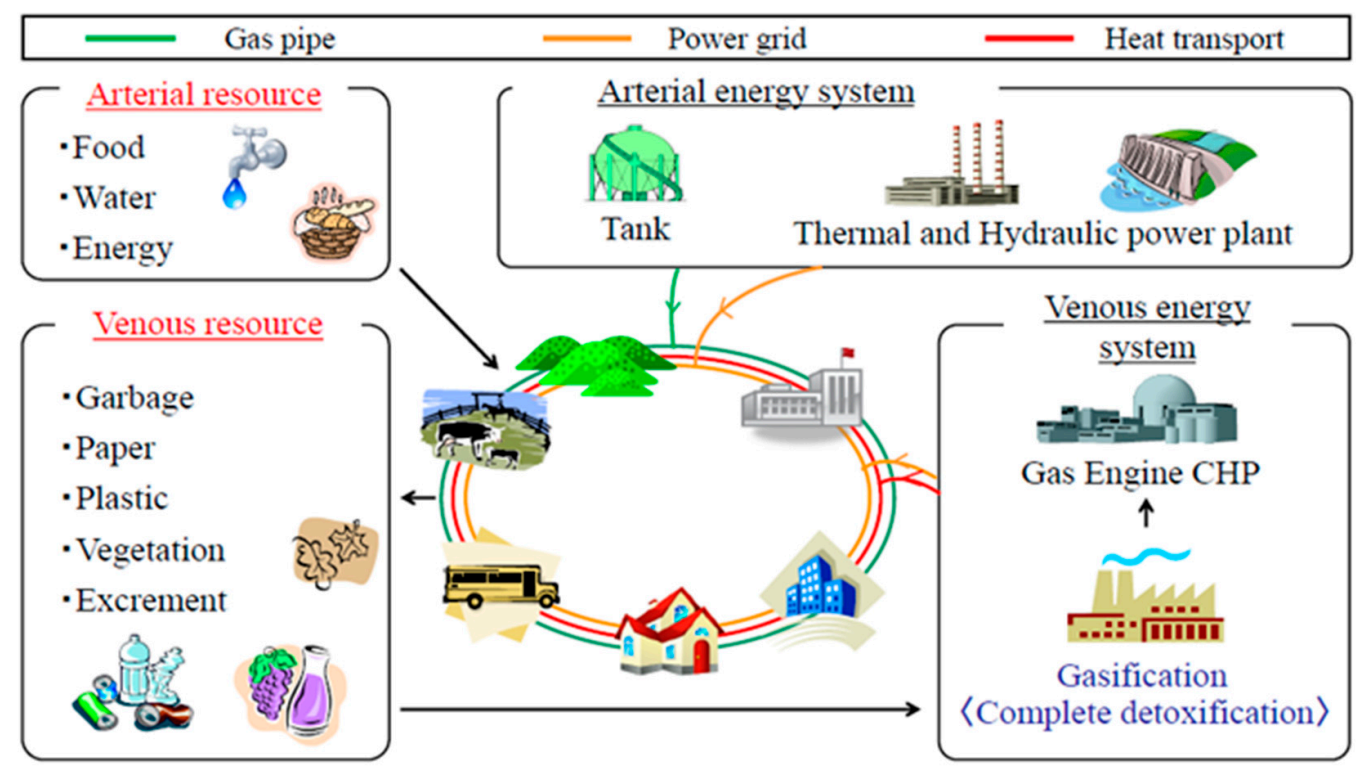

Figure 1. Holonic approach to a city energy generation system [8].

The concept presented by Ushida (2012) is attracting attention as global warming and sustainability concerns, the reduction of fossil fuel dependency, and an efficient waste management are urgent matters in the current energy context. The system proposed in this report is based on using venous resources to reduce the system dependency on hard energy paths derived from the artery system. In this case, the waste to energy plant (i.e., biomass gasification plants) located at the mall and the solar energy panels installed on the rooftop of the mall both represent the venous energy system, which could improve the energy self sustainability of the region and create a zero waste society. All the waste generated by the 
mall (e.g., stores, restaurants, leisure facilities) and the community analyzed is recycled and used in the gasification process, which is explained in Section 3 [8].

In this research, the holonic approach shown in Figure 1 has been applied. The main target is to create and analyze the economic and environmental sustainability of a mall and its surrounding neighborhood. Therefore, the following economic, environmental and energetic parameters have been analyzed: payback time, net present value, levelized cost of energy, $\mathrm{CO}_{2}$ emissions reduction ratio and energy efficiency ratio.

The present report optimizes the superheated steam gasification process, compares it with other waste to energy technologies, studies its combination with solar photovoltaic panels, and analyzes the influences of plastics in the process by defining several cases which are later explained in Section 4.

\section{Analysis Conditions}

The analyzed system is composed of a distributed generation system which includes a fictitious medium size mall, Table 1 , which is surrounded by a community of 20,000 inhabitants, Table 2, located in Kyoto, Japan.

In Figure 2, the analyzed system is represented. Municipal solid waste is collected from both the mall and the community, and it is later transported to the waste gasification plant which is located at the mall. Then, the gasification plant generates electricity from the municipal solid waste collected and delivers part of that electricity back to the community.

Table 1. Medium size mall. Specification.

\begin{tabular}{lc}
\hline Store area & $30,100 \mathrm{~m}^{2}$ \\
\hline Electricity demand & $346.16 \mathrm{kWh} / \mathrm{m}^{2} \cdot \mathrm{y}$ \\
\hline Municipal solid waste generation & $76.65 \mathrm{~kg} / \mathrm{m}^{2} \cdot \mathrm{y}$ \\
\hline
\end{tabular}

Table 2. Small-medium size neighborhood. Specification.

\begin{tabular}{lc}
\hline Population & 20,000 inhabitants \\
\hline Electricity demand & $904.18 \mathrm{kWh} /$ population $\cdot \mathrm{y}$ \\
\hline Municipal solid waste generation & $226 \mathrm{~kg} /$ population $\cdot \mathrm{y}$ \\
\hline
\end{tabular}

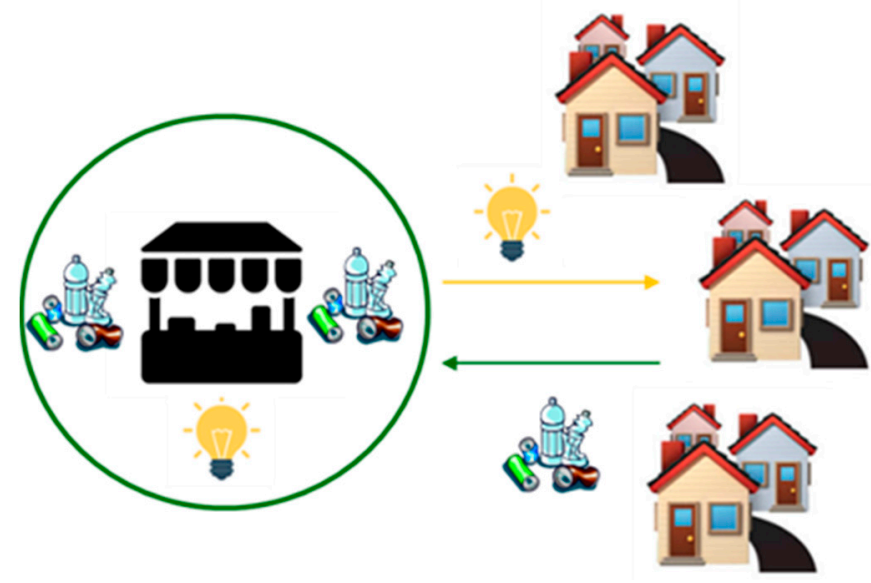

Figure 2. System analyzed in this research.

\section{Energy Generation Process}

\subsection{Energy Generation Background}

The proposed energy generation system consists of five stages, as shown in Figure 3: (i) collection and transportation; (ii) chipping; (iii) drying; (iv) gasification; and (v) power generation. Since waste biomass is not a suitable fuel for the gasification process, it is 
necessary to carry out a pretreatment process, which consists of reducing the solid waste biomass size (i.e., chipping) and decreasing the moisture content by applying heat to the solid waste (i.e., drying). During the gasification stage, pretreated biomass is converted into syngas by thermal conversion. Finally, the syngas is introduced into a CHP gas engine, where power and heat are generated. The heat energy produced can be used in order to substitute city gas consumption in the drying and gasification stages [9].

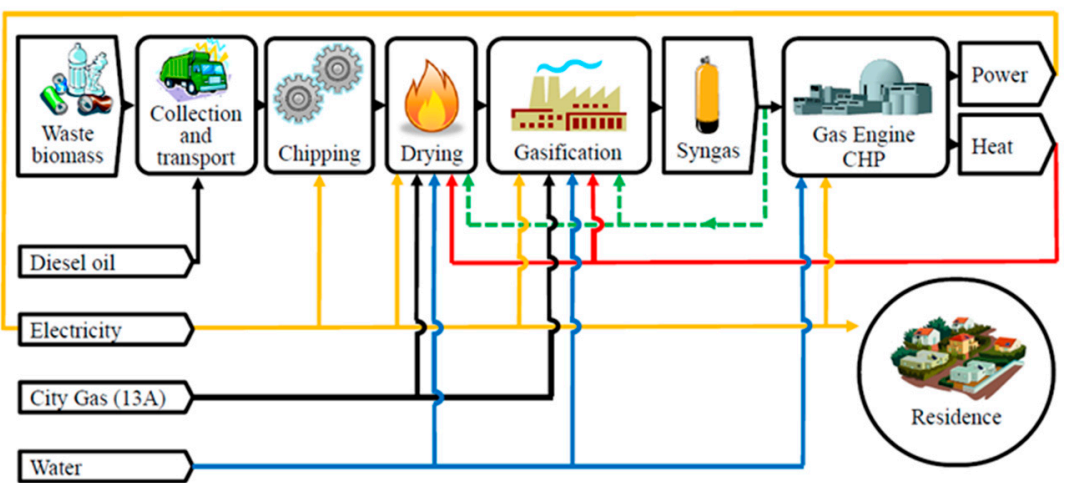

Figure 3. Schematic diagram of the overall energy generation process.

\subsection{Collection and Transportation}

In this report, the collection and transportation distances have been calculated with the help of the grid city model shown in Figure 4 [10]; the GC Model has a uniform population distribution with roads as grids. It is assumed that the area is rectangular and the vehicles travel along the roads. The collection stations are represented by nodes. Vehicles have a capacity of four tons and their loading rate is $50 \%$.

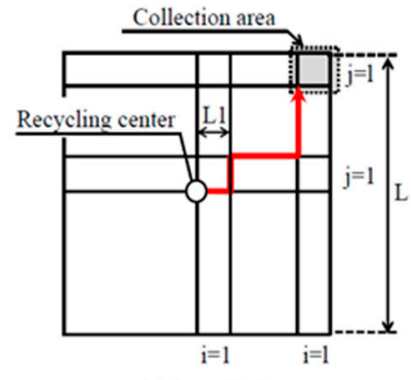

(a) Overall view

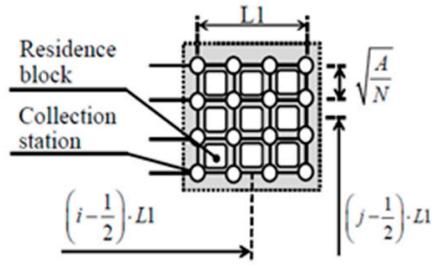

(b) Close up of collection area

Figure 4. Geometry of grid city model: (a) Overall view; (b) Close up of collection area.

\subsection{Pretreatment Stages: Chipping and Drying}

The main goal of the chipping stage is to minimize the size of solid waste in order to increase gasification efficiency and prevent damaging the machinery. Each type of feedstock requires different chipping machines: for garbage waste the FUJITEX E020 machine has been selected, for papers the FUJITEX E007 machine, for plastics the FUJITEX E013 is used and for wood the FUJITEX E027 is required [9,11].

After chipping the material, it is highly recommended to reduce the moisture content down to $20 \%$. If biomass moisture content is high, gasification efficiency decreases. It is proposed to use the KENKI dryer, which is a continuous low temperature drying machine. It is composed of synchronized twin screw conveyors that carry the material through the chamber. The KENKI dryer is a suitable machinery for this process due to its waste flexibility: this machine is able to process all the types of municipal solid waste previously mentioned. The process requires saturated steam as a heating source in order to obtain a dried, uniform, and stable material [4]. It is easily maintained and has a long term durability [12]. 
In order to meet with the requirements, it is also necessary to install a boiler, which is in charge of creating enough saturated steam to use as a heating source. This report proposes the usage of SQ-3000AS boiler from Miura Kogyo Co. [13].

\subsection{Gasification}

In this research, the superheated steam gasification plant analyzed is the one used in the demonstration test of the K2-PEC (Kyoto Keihanna Perfect Energy Converter), this system is considered as a moving grate gasification system. Figure 5 shows a schematic diagram of the system. In this plant, after the solid waste has been introduced to the gasifier, superheated steam- $1073 \mathrm{~K}$-is sprayed to reform the gas under anoxic conditions, without oxygen. Then, the resultant gas, syngas, is cooled down and washed before injecting it into a buffer tank [14].

This device can handle a processing speed between $30 \mathrm{~kg} / \mathrm{h}$ and $5000 \mathrm{~kg} / \mathrm{h}$ of pretreated solid waste and it is suitable for small-medium size plants. Both the energy consumption and the initial investment increase is a proportion of $2 / 3$ of the processing speed. The energy consumption increases due to the effect of heat dissipation and the initial investment increases due to the plant scale of merit as observed in Figure 6.

It is necessary to install a buffer tank in between the gasifier and the gas engine in order to cover the syngas demand efficiently. It is important to adjust the fluctuations in the amount of gas generated in the gasification stage and delivered to the power generation stage. A compressor is also installed in front of the buffer tank with the objective of maintaining the gauge pressure inside the buffer tank at $0.7 \mathrm{MPa}$.

Two different gasification systems are compared in this report: superheated steam gasification (moving grate) and downdraft air gasification. In superheated steam gasification, the gasifying agent is steam and the geometry of the system allows a more stable and uniform temperature distribution creating a higher quality syngas. In contrast, in downdraft gasification, the gasifying agent is air which reduces the cold gas efficiency of the system [15] and, therefore, the low heating value of the syngas created. Table 3 compares the most relevant specifications of both systems.

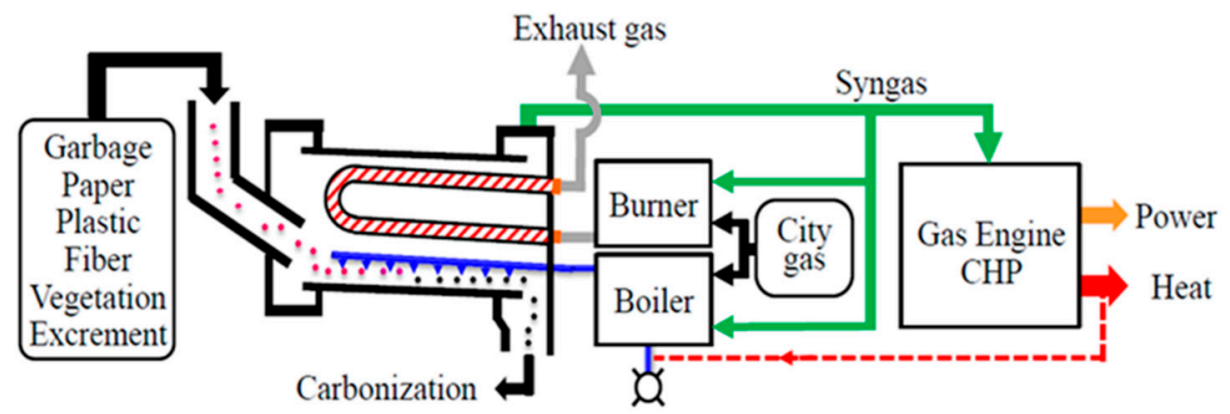

Figure 5. Schematic diagram of superheated steam gasification system. 


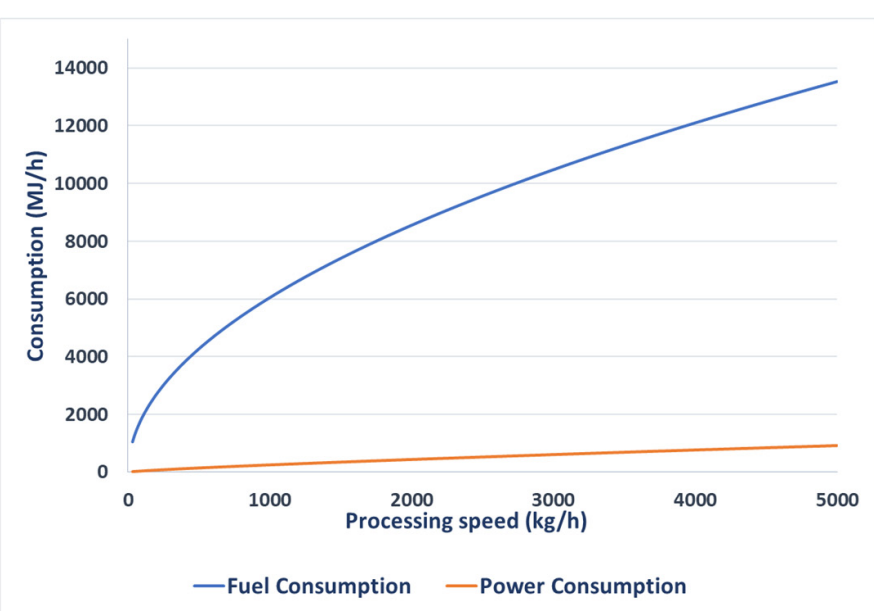

(a)

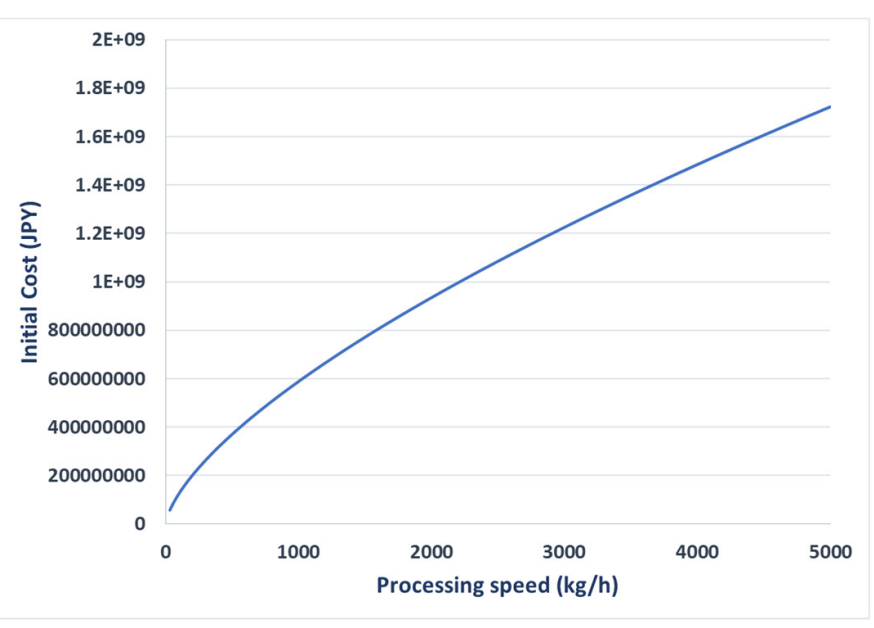

(b)

Figure 6. Gasification system specifications: (a) Fuel and power consumption over processing speed; (b) initial cost over processing speed.

Table 3. Gasification specifications.

\begin{tabular}{lcc}
\hline Type of Gasification & $\begin{array}{c}\text { Superheated Steam } \\
\text { Gasification }\end{array}$ & Downdraft Gasification \\
\hline Cold gas efficiency & $85 \%$ & $60 \%$ \\
Power plant capacity & $0.66 \mathrm{MW}$ & $0.50 \mathrm{MW}$ \\
Fuel consumption & $6578 \mathrm{MJ} / \mathrm{h}$ & $4276 \mathrm{MJ} / \mathrm{h}$ \\
Machine cost & $624,301,410 \mathrm{JPY}$ & $405,795,917 \mathrm{JPY}$ \\
Service life & $15 \mathrm{y}$ & $15 \mathrm{y}$ \\
\hline
\end{tabular}

\subsection{Power Generation Process}

The power generation stage includes a gas engine $\mathrm{CHP}$ with high overall efficiency to generate electricity from the syngas stored in the buffer tank; the gas engine selected is the 275 kW capacity Yanmar, CP 275 D1-TNJG [16].

Ideally, it would be preferable to supply heat energy to the nearby neighborhood, however, it is difficult to supply heat efficiently to distant houses. Due to this fact, it is proposed to install a waste heat interchange system composed of the exhaust gases from gasification and hot water. This energy recovery system allows the reutilization of part of the heat energy for the gasification process, reducing the city gas consumption and, therefore, achieving a higher autonomy of the system.

\subsection{Solar Energy Generation}

In this report, it is proposed to create an energy generation system which combines photovoltaic panels and waste gasification. Table 4 shows the following specifications from the solar energy system: type of panel selected, shopping mall characteristics such as the suitable ratio, the roof space/gross leasable area, the availability ratio, location characteristics such as global radiation, and the covering ratio that is related to the latitude and the tilt angle.

Among all photovoltaic technologies, multicrystalline panels have been chosen, since they achieve the best compromise between price and efficiency [17]. Multicrystalline silicon cells are made from an ingot of melted and recrystallized silicon. Generally, the initial investment of these panels is more than monocrystalline panels, however their efficiency tends to be also slightly lower. 
Table 4. Solar energy specifications.

\begin{tabular}{cc}
\hline Type of Panel & Multicrystalline \\
\hline Initial cost of PV system & 180 yen $/ \mathrm{W}$ \\
\hline Max. power (STC) & $300 \mathrm{~W}$ \\
\hline Efficiency & $16 \%$ \\
\hline Roof space/GLA ratio & $58 \%$ \\
\hline Suitable ratio & $80 \%$ \\
\hline Availability ratio & $65 \%$ \\
\hline Covering ratio (Kyoto) & $49 \%$ \\
\hline
\end{tabular}

\section{Evaluation Methodology}

In order to analyze the process previously explained, four different cases have been created. In addition, superheated steam gasification technology is compared with other waste to energy techniques like downdraft air gasification and direct combustion.

1. Case 1: municipal solid waste (MSW) is collected from the mall and the surrounding neighborhood; the energy generation system is composed of only waste gasification;

2. Case 2: MSW is collected from the mall and the surrounding neighborhood; the energy generation system is composed of waste gasification and photovoltaic panels. This case analyzes the addition of solar energy to the system;

3. Case 3: MSW is collected from the mall and the surrounding neighborhood with the peculiarity that plastics are not collected. The energy generation system is composed of only waste gasification. This case analyzes the absence of plastics in the system;

4. Case 4: MSW is collected only from the mall; the energy generation system is composed of waste gasification and photovoltaic panels. This case analyzes the influence of the processing collection fee.

In order to study the four cases and compare the three different waste to energy techniques, several economic, environmental and energetic parameters are defined.

\subsection{Economic Parameters}

Payback time, Equation (1), studies the period of time until the return of the initial investment is completed; hence, it studies the economic behavior of the system in a short period of time. On the other hand, net present value (NPV), Equation (2), and levelized cost of electricity (LCOE), Equation (3), study the long term behavior of the system. NPV studies the profits over a period of 30 years, taking into consideration the present inflation ratio, and LCOE analyzes the cost of the electricity generated during the following 30 years.

$$
\begin{gathered}
\text { Paybck Time }=\frac{I C}{C F_{N E T}} \\
\text { Net Present Value }=\frac{\sum_{1}^{30} C F_{N E T}-I C}{\sum(1+i)^{30}} \\
\text { Levelized Cost of Energy }=\frac{I C+\sum_{1}^{30} R C}{\sum_{1}^{30} W_{E}}
\end{gathered}
$$

where IC is initial investment (yen); $C F_{N E T}$ is Net Cash Flow (yen/y); $i$ is the inflation rate $(-) ; R C$ is running costs (yen/y); and $W_{E}$ is energy generated (kWh/y). 


\subsection{Environmental Parameters}

$\mathrm{CO}_{2}$ Reduction Ratio, Equation (4), compares the emissions decrement between the two different systems. In this paper, "traditional" refers to the energy mix, whereas "new" refers to the distributed energy generation system proposed in this research.

$$
\mathrm{CO}_{2} \text { Reduction Ratio : } \Delta \mathrm{CO}_{2}=\frac{\mathrm{CO}_{2, \text { trad }}-\mathrm{CO}_{2, \text { new }}}{\mathrm{CO}_{2, \text { trad }}}
$$

To calculate this parameter, it was necessary to create a life cycle assessment covering the whole energy generation system from tank to wheel. However, part of the scrapping stage should also be taken into consideration, since in the last part of the process there is a substantial difference between the traditional system and the alternative system proposed. The new system does not landfill solid waste, in contrast with traditional energy generation systems; solid waste landfilled produces an average of $270 \mathrm{~kg} \mathrm{CO}_{2}$ per ton of MSW.

\subsection{Energetic Parameters}

Electricity saving ratio (ESR), Equation (5), studies the electricity supply independence from the state network. Energy efficiency ratio (EER), Equation (6), analyzes the energy generated over the energy input of the system, in other words, it studies the energetic conversion ratio of the system.

$$
\begin{gathered}
\text { Electricity Saving Ratio }=\frac{W_{E}-\left(\sum E_{\text {process }}\right)}{D_{\text {elec }}} \\
\text { Energy Efficiency Ratio }=\frac{W_{E}}{E_{f e e d}+E_{\text {city gas }}+E_{\text {elec }}}
\end{gathered}
$$

where $E_{\text {process }}$ is the energy consumption of the process $(\mathrm{kWh} / \mathrm{y}) ; D_{\text {elec }}$ is energy demand $(\mathrm{kWh} / \mathrm{y}) ; E_{\text {feed }}$ is the solid waste low heating value $(\mathrm{kWh} / \mathrm{y}) ; E_{\text {city gas }}$ is city gas consumption $(\mathrm{kWh} / \mathrm{y})$; and $E_{\text {elec }}$ is electricity consumption $(\mathrm{kWh} / \mathrm{y})$.

\section{Results and Discussion}

\subsection{Optimization of Superheated Steam Gasification Process: Case 1}

Before comparing superheated steam gasification with other waste to energy systems, it is convenient to optimize the current system and reduce its payback time. The main goal from an economic perspective is to reduce the payback time to 10 years. In previous researches from Doshisha Seniors, the payback time of the superheated steam gasification was 17 years.

In the transportation and collection stages, the grid city model was applied in order to reduce the trucks' working time and, therefore, the fuel costs. In this model, roads are assumed to be grids and collection stations are represented as nodes in a uniform population distribution. The time required for this stage is divided into collection time and transportation time, where the truck speeds are $15 \mathrm{~km} / \mathrm{h}$ and $50 \mathrm{~km} / \mathrm{h}$, respectively. For this particular case, Case 1, the number of trucks required is eight and their working time is four hours per day.

In the chipping, drying and power generation stages, machines have been sized by contacting with companies in order to find the most suitable machines for Case 1. Two FUJITEX E020 (Garbage), two FUJITEX E007 (Paper), two FUJITEX E013 (Plastics) and one FUJITEX E027 (wood) are required in the chipping stage; the total amount of time needed per day to grind all the solid waste collected is five hours. Four KENKI dryers and one SQ-3000AS Boiler are required in the drying stage; six hours are necessary in this stage to dry out all the collected waste. In the power generation stage, five YANMAR CP 275 D1-TNJG are required to process all the syngas produced in the superheated gasification process; they run for $11 \mathrm{~h}$. 
Energy coming from plastics is not economically rewarding since its selling price is 0 yen $/ \mathrm{kwh}$. Therefore, electricity generated from plastics should be used for the electricity consumption process and for the mall demand, whereas the electricity generated coming from the other types of feedstock should be sold to the nearby neighborhood users. If the electricity consumption process and part of the mall electricity demand is covered by the electricity generated from plastics, it will not be necessary to purchase this energy from the main state grid, reducing the payback time of the system until two years.

The optimization of the gasification stage is focused on finding the optimum operation time to reduce the payback time. Figure 7a shows that the optimum operation time for the minimum levelized cost of energy over a period of 30 years is eight hours per day. If the operation time is increased, in order to process the same amount of solid waste, the gasification plant size must be reduced, and, therefore, the initial investment is also reduced. However, if the operation time is increased, the fuel consumption increases since the plant is in operation mode for a longer period of time.

Figure $7 \mathrm{~b}$ compares two cases depending on the gasification operation time. The first case, which analyzes the optimum operation time, $8 \mathrm{~h}$, prioritizes the economic performance. On the other hand, the second case, which studies an operation time of $3 \mathrm{~h}$, prioritizes the environmental performance.

It can be observed that the payback time is reduced from 14.35 years to 9.98 years by increasing the operation time from three to eight hours. However, the $\mathrm{CO}_{2}$ reduction ratio is decreased in the economic case in comparison with the environmental alternative, from $43.81 \%$ to $35.47 \%$ due to the larger amount of city gas required to heat up the gasifier.

Therefore, Figure $7 \mathrm{~b}$ shows two cases with complementary objectives: if the priority is to reduce the payback time, eight hours gasification operation time must be selected, on the other hand, if the main objective is to greatly reduce $\mathrm{CO}_{2}$ emissions, three hours gasification operation time is a better alternative. In the following sections of this research, the economic case $(8 \mathrm{~h}$ ) will represent Case 1 since lowering the payback time is the number one priority of this research.

\subsection{Comparison with Other Waste to Energy Techniques}

It is known that superheated steam gasification is a high efficient technology, however, it is considered to have larger initial investment than other waste to energy technologies such as downdraft air gasification or direct combustion.

The main advantages of superheated steam gasification compared to the other systems are its high cold efficiency, $85 \%$, that leads to a high syngas quality, LHV is $8-10 \mathrm{MJ} / \mathrm{Nm}^{3}$, and the low amount of pollutants generated such as $\mathrm{CO}_{2}, \mathrm{NOx}$, SOx, particulates, etc. Downdraft air gasification cold efficiency is $60 \%$, leading to a syngas LHV of $4-7 \mathrm{MJ} / \mathrm{Nm}^{3}$, which is still higher than direct combustion. The main advantage of downdraft air gasification is the very low tar content present in the syngas which reduces maintenance costs. The main advantage of direct combustion is the low initial investment of the system. 


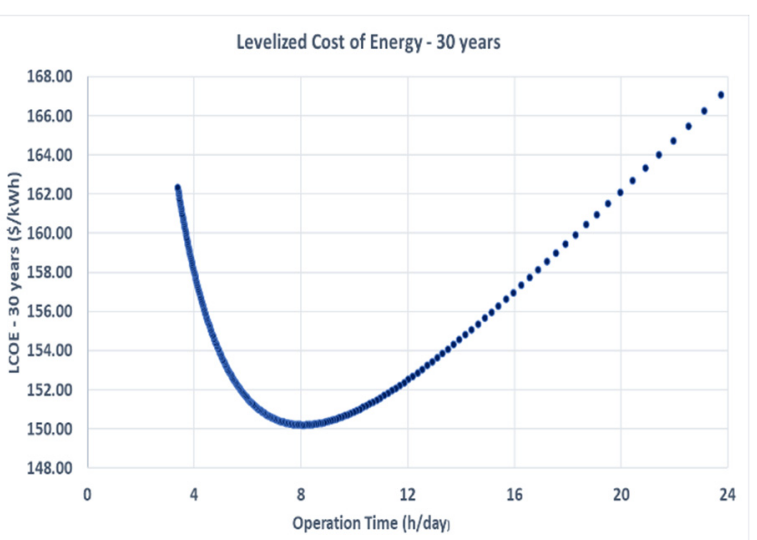

(a)

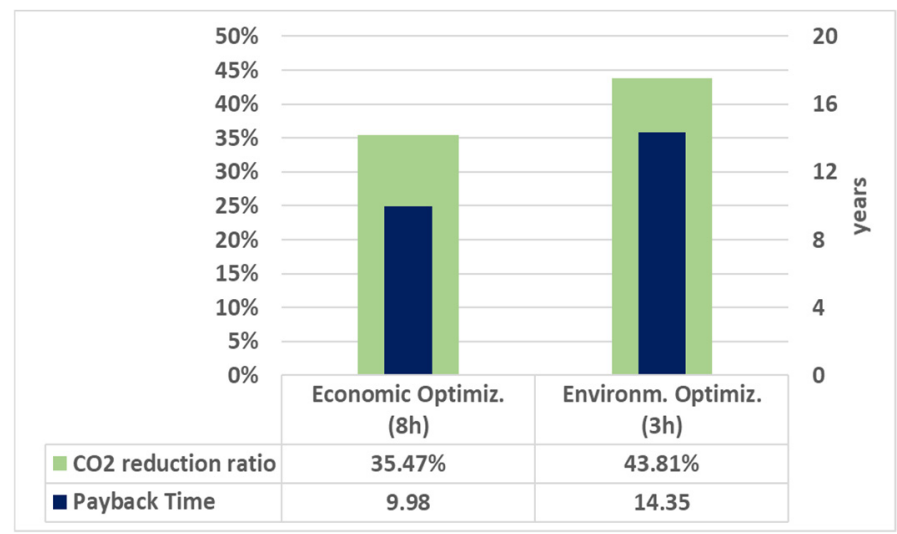

(b)

Figure 7. Optimization of Superheated Steam Gasification Process: (a) Economic optimum gasification operation time; (b) comparison between $8 \mathrm{~h}$ and $3 \mathrm{~h}$ gasification operation time.

Figure 8 compares economic parameters among the three waste to energy systems analyzed. Payback time studies the economic short term performance, whereas net present value (NPV) analyzes the profitability of the system over a long period of time, 30 years. By comparing the payback time, the direct combustion system obtains the lowest value due to its low initial investment. However, if the NPV over 30 years is analyzed, superheated steam gasification is the most profitable option followed closely by downdraft gasification.

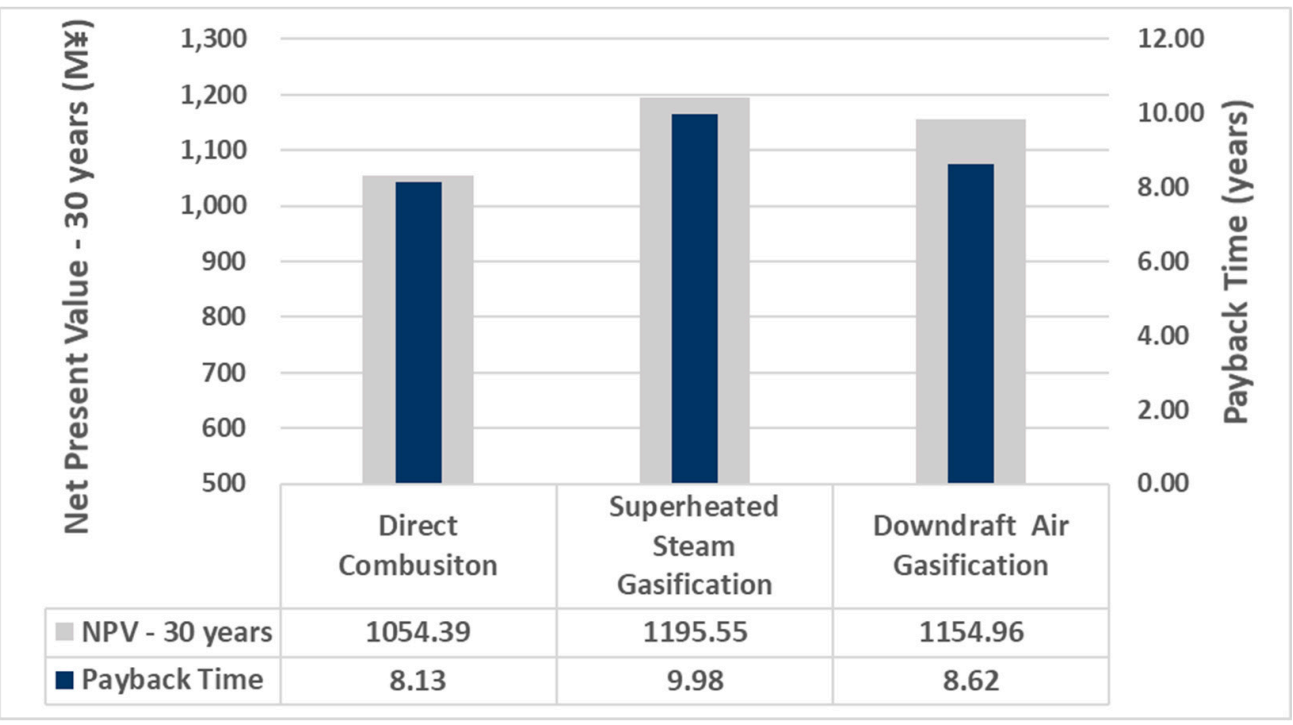

Figure 8. Comparison of three waste-to-energy techniques from an economic perspective.

The reason behind this result is related to the higher power plant capacity of the superheated steam gasification system, $0.66 \mathrm{MW}$ compared to the alternative options, direct combustion of $0.19 \mathrm{MW}$ and downdraft air gasification of $0.50 \mathrm{MW}$. The higher amount of electricity produced generates much more revenue when the electricity is sold to the nearby community. Since the service life of energy projects is considerably high, it is recommendable to focus on the long term performance, in which superheated steam gasification obtains the best results.

From Figure 9, it is observed that the environmental and energetic parameters are related. Superheated steam gasification obtains the highest $\mathrm{CO}_{2}$ reduction ratio. This is due to the high efficiency of the system that is capable of generating more electricity with the same MSW. Direct combustion produces more $\mathrm{CO}_{2}$ than the traditional energy generation 
system and MSW landfill. So, from an environmental point of view, direct combustion is clearly the worst option among the three studied.

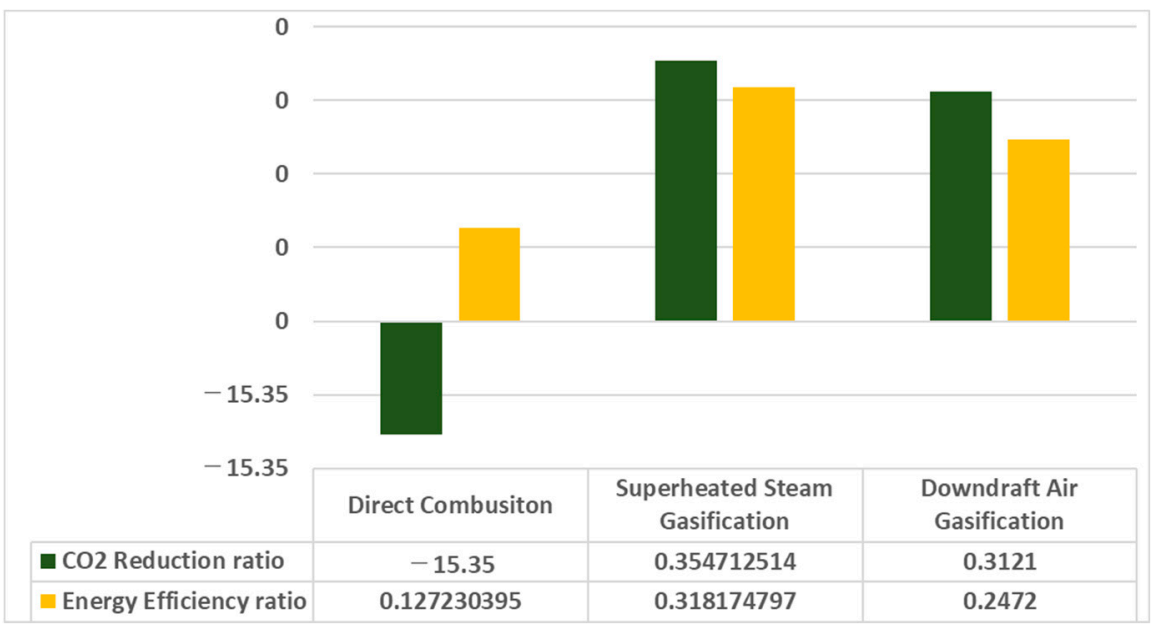

Figure 9. Comparison of three waste to energy techniques from an environmental and energetic perspective.

\subsection{Influence of Solar Energy and Plastic Usage}

One of the main objectives of this research is to create a microgrid composed of biomass, superheated steam gasification, and solar energy photovoltaic panels. In order to study the influence of adding photovoltaic panels to the system and the influence that plastics have on the system, four cases were introduced in Section 4.

The multicrystalline photovoltaic panels are located at the rooftop of the mall. The maximum number of PV panels that can be installed on the rooftop are 2365 panels. The usage of batteries is rejected, since the electricity produced from these panels is lower than the electricity demand from the mall and the nearby community.

The power plant capacity of the solar energy generation system is $0.11 \mathrm{MW}$, which is summed to the power plant capacity of the superheated steam gasification process, resulting in a total power plant capacity of $0.77 \mathrm{MW}$ (Case 2).

Figure 10a compares the payback time of the four cases analyzed. Case 2 (biomass and solar energy) obtains the lowest payback time, 9.83 years, due to the addition of solar energy generation system, which have a payback time of 8.56 years. Case 3 represents the absence of plastics; the usage of plastics decreases the amount of electricity generated and hence the revenue streams obtained. Case 4 has an extremely high payback time, this is due to the fact that it only collects MSW from the mall and therefore the system does not receive the solid waste processing collection fee. If collection taxes were removed from the government since the system is taking care of the waste produced by the mall, the payback time of Case 4 would decrease to 17.42 years which is still a very high value taking into consideration the service life of the system.

Figure $10 \mathrm{~b}$ compares the profitability of each case over 30 years in M¥; in the long-term, Case 2 also obtains the best performance among the four cases. It is clear that the addition of solar energy has a positive economic impact in the system. However, the absence of plastics has a negative impact on the economic performance. 


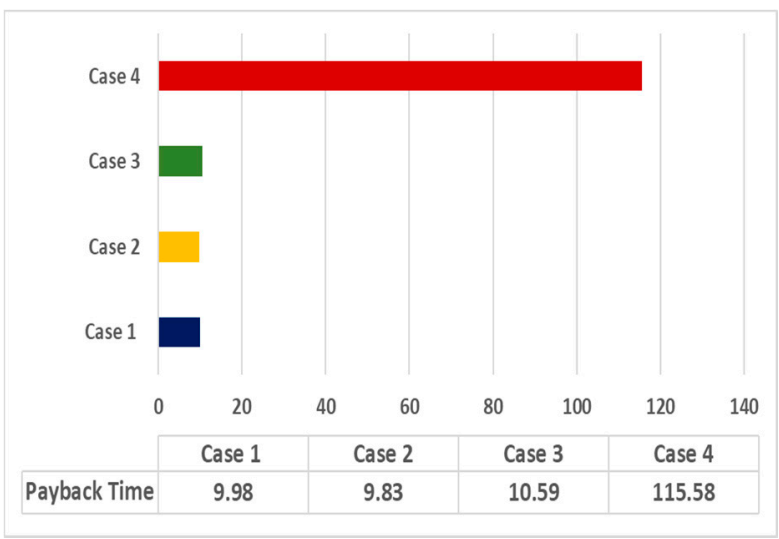

(a)

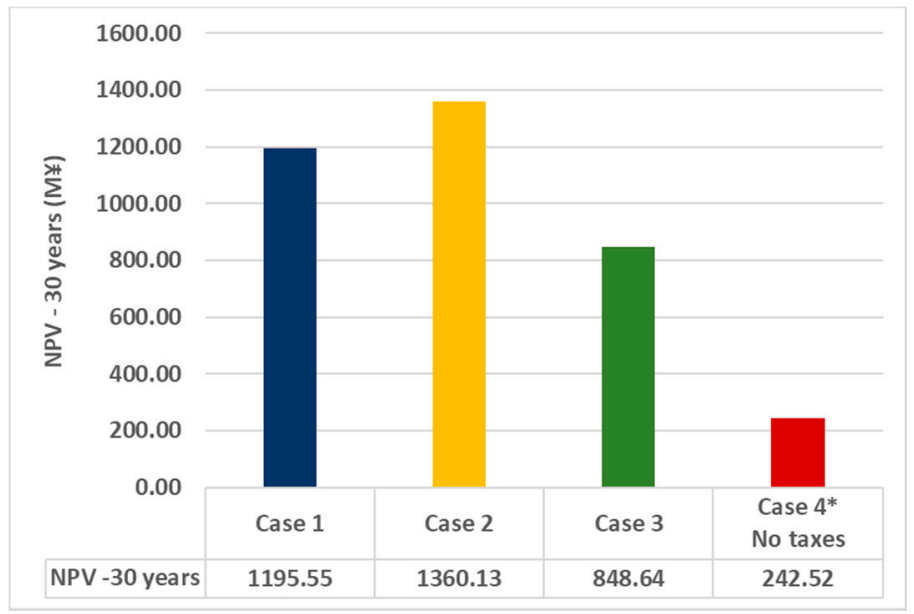

(b)

Figure 10. Influence of Solar Energy and Plastic Usage: (a) Payback time analysis; (b) net present value analysis.

In Figure 11, both environmental and energetic parameters are analyzed. It is observed that both the $\mathrm{CO}_{2}$ reduction ratio and electricity saving ratio are related in every case except for Case 3. In Case 3, the lack of plastics increases the $\mathrm{CO}_{2}$ reduction ratio during gasification. On the contrary, plastics possess a high calorific power, therefore, their absence from the system considerably reduces the amount of energy generated. The power plant capacity of Case 3 is $0.43 \mathrm{MW}$, which is lower than Case 1 or Case 2, $0.67 \mathrm{MW}$ and $0.77 \mathrm{MW}$, respectively.

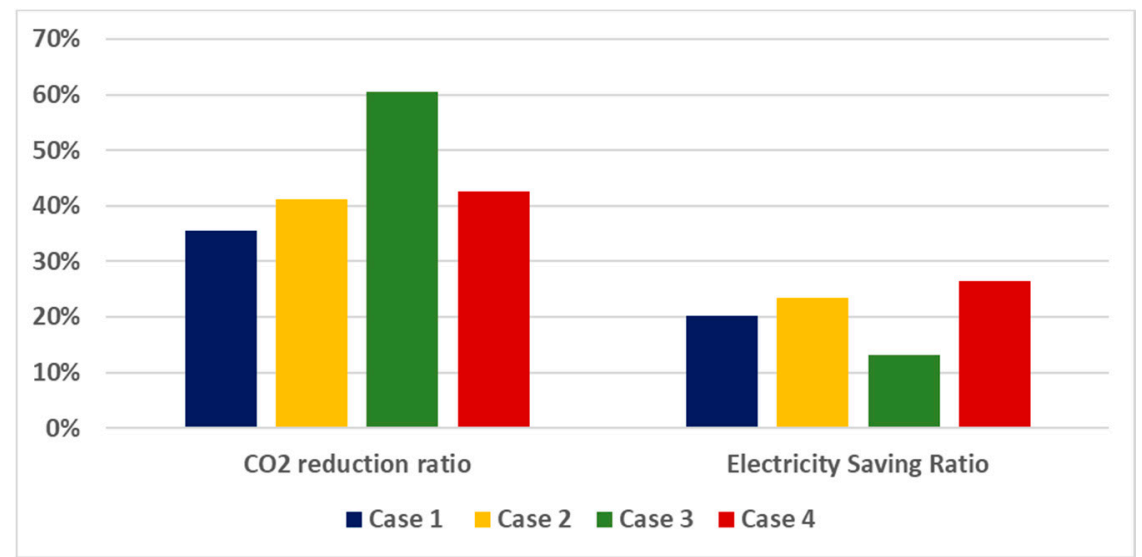

Figure 11. $\mathrm{CO}_{2}$ reduction ratio and Electricity Saving Ratio Analysis.

Figure 9 also shows that the combination of waste gasification and photovoltaic panels (Case 2) increases the $\mathrm{CO}_{2}$ reduction ratio to $41 \%$ and the electricity saving ratio to $24 \%$. Therefore, it can be concluded that for the analyzed conditions, the addition of solar energy to the system achieves a better performance from an energetic, environmental and economic perspective, than Case 1.

\section{Conclusions}

In light of the above mentioned, it is clear that waste to energy techniques could be a feasible option in order to reduce fossil fuel dependency in developed countries. However, the system must be economically optimized by reducing its payback time down to 10 years. In this report, the superheated steam gasification system has been optimized by using the grid city model, sizing machines, optimizing the electricity selling distribution and selecting an optimum gasification operation time of eight hours, resulting in a reduction in the payback time from 17 years to 9.98 years (Case 1). The increment in operation time leads 
to better economic parameters. However, the increment in the gasification operation time also leads to higher city gas consumption, which increases the amount of $\mathrm{CO}_{2}$ produced in the system.

Superheated steam gasification is the most suitable waste to energy system among the three compared in this report, since it achieves the best economic performance in the long term, as well as the best environmental and energetic performances.

Results show that a distributed generation system composed by waste superheated steam gasification and photovoltaic panels (Case 2) is perfectly feasible since its payback time is 9.83 years and its long term economic performance shows high profitability. This system is able to reduce by $41 \%$ the amount of $\mathrm{CO}_{2}$ generated in comparison with traditional energy generation and municipal solid waste landfill. Therefore, solar energy has a positive effect on long term economic and environmental parameters. On the other hand, the absence of plastic usage has a negative impact on energetic and economic parameters and a positive impact in $\mathrm{CO}_{2}$ reduction ratio (Case 3).

However, superheated steam gasification shows two main drawbacks which are important to mention. First, the system depends largely on the solid waste processing collection fee since it represents almost $40 \%$ of the total income of the system. This could be a weak point since the fee is given through public tender by the government. Second, the system is not independent from the state network since it requires city gas to heat up the gasifier in the gasification process; city gas fuel consumption cost represents the $51 \%$ of the total running costs of the system.

\section{Future Steps}

As future steps, I would like to introduce an innovative concept called $\mathrm{CO}_{2}$ capture and mineralization, which is starting to be used by high tech energy companies in Europe. The main objective of this technology is to drastically reduce the $\mathrm{CO}_{2}$ emissions of the superheated steam gasification process by capturing the $\mathrm{CO}_{2}$ produced during the gasification process and reusing the $\mathrm{CO}_{2}$ in the mineralization process [18].

The objective of the mineralization process is the manufacturing of construction materials, such as concrete, by using the $\mathrm{CO}_{2}$ captured previously during the gasification stage. This process needs the $\mathrm{CO}_{2}$ captured from gasification; industrial mineral waste, such as ashes, from the gasification system; water; and cement aggregates, as is shown in Figure 12. The process does not require external energy since the reaction is exothermic. Mineralization is a natural reaction that takes a long time; therefore, it is necessary to accelerate the reaction in order to obtain concrete or other construction materials [19].

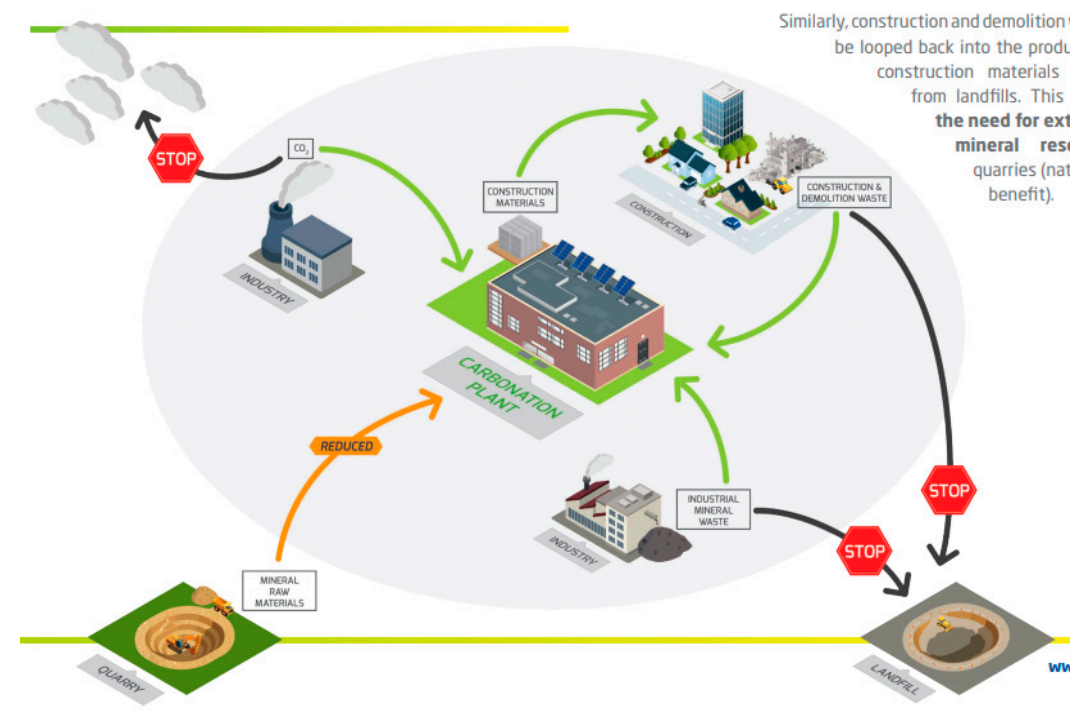

Figure 12. $\mathrm{CO}_{2}$ Capture and Mineralisation Schematic Diagram. 
This technique would create a circular economy in the system, drastically reduce the $\mathrm{CO}_{2}$ emissions of the system, add a new income stream to the system by selling materials to the building and construction industries, and improve the industrial waste management.

Author Contributions: Investigation, A.Q.G.; conceptualization, A.Q.G., A.S., E.M. and J.S.; resources, A.Q.G., A.S., E.M. and J.S.; methodology, A.Q.G., A.S., E.M. and J.S.; supervision, A.S., E.M. and J.S.; writing—original draft preparation, A.Q.G.; writing-reviewing and editing, N.N. All authors have read and agreed to the published version of the manuscript.

Funding: This research received no external funding.

Institutional Review Board Statement: Not applicable.

Informed Consent Statement: Not applicable.

Acknowledgments: The authors are thankful to Jiro Senda and Eriko Matsumura (The Mechanical Engineering Department in Doshisha University) for valuable guidance andf constant support.

Conflicts of Interest: The authors declare no conflict of interest.

\section{References}

1. Akai, M. Long Term Energy Scenario: A Challenge to the Climate Change. J. Gas Turbine Soc. Jpn. 2012, 30, 6-12.

2. Akhtar, A.; Krepl, V.; Ivanova, T. A Combined Overview of Combustion, Pyrolysis, and Gasification of Biomass. Energy Fuels 2018, 32, 7294-7318. [CrossRef]

3. Porteus, A. Why energy from waste incineration is an essential component of enviromentally responsibe waste management. Waste Manag. 2005, 25, 451-459. [CrossRef] [PubMed]

4. Arena, U. Process and technological aspects of municipal solid waste gasification. A review. Waste Manag. 2012, 32, 625-639. [CrossRef] [PubMed]

5. Consonni, S.; Vigano, F. Waste gasification vs. conventional Waste-To-Energy: A comparative evaluation of two commercial technologies. Waste Manag. 2012, 32, 653-666. [CrossRef] [PubMed]

6. Famoso, F.; Prestipino, M.; Brusca, S.; Galvagno, A. Designing sustainable bioenergy from residual biomass: Site allocation criteria and energy/exergy performance indicators. Appl. Energy 2020, 274, 115315. [CrossRef]

7. Chicco, G.; Pierluigi, M. Distributed multi-generation: A comprehensive review. Renew. Sustain. Energy Rev. 2009, 13, 535-551. [CrossRef]

8. Ushida, Y.; Sakai, T.; Senda, J. 102 Modeling Analysis for Life Cycle Assessment of Waste Energy Recycling Society. Japan Society of Mechanical Engineers: Tokyo, Japan, 2012. Available online: https://www.jstage.jst.go.jp/article/jsmepes/2012.17/0/2012.1 7_169/_pdf/-char/ja (accessed on 1 December 2019).

9. Tanaka, M.; Seguchi, D.; Sugawara, R.; Alvaro, Q.; Saito, A.; Matusumura, E.; Senda, J. Construction and Evaluation of Platform for Superheated Gasification Power Generation System using Waste Biomass; Japan Society of Mechanical Engineers: Tokyo, Japan, 2020. Available online: https://www.jstage.jst.go.jp/article/jsmekansai/2020.95/0/2020.95_09_910/_article/-char/ja/ (accessed on 16 May 2020).

10. Ishikawa, M. A logistics Model for Post-Consumer Waste Recycling. J. Packag. Sci. Technol. Jpn. 1996, 5, 119-130. (In Japanese)

11. Fujitex Co. (n.d.). Available online: https://www.fjtex.co.jp/kankyo/ (accessed on 1 December 2018).

12. Kenki Dryer Co. (n.d.). Available online: https://kenkidryer.com/products/spesifications (accessed on 25 January 2019).

13. Miura Kogyo Co. (n.d.). Miura Boiler. Available online: https:/ / www.miuraboiler.com/steam-boilers (accessed on 25 January 2019).

14. Keer, L.M.; Knapp, W.; Hocken, R. Resonance Effects for a Crack Near a Free Surface. Trans. ASME J. Appl. Mech. 1986, 51, 65-69. [CrossRef]

15. Muthu Dinesh Kumar, R.; Arnand, R. Production of Biofuel from Biomass downdraft gasification and its applications. In Advanced Biofuels; Woodhead Publishing: Cambridgeshire, UK, 2019. Available online: https://www.sciencedirect.com/topics/ engineering/downdraft-gasifiers (accessed on 3 January 2019).

16. Yanmar Co. Yanmar CP35 Brochure Web. from Yanmar's 35 kW Combined Heat and Power System. 2016. Available online: www.yanmar-es.com/wp-content/uploads/YANMAR-CP35-Brochure-Web.pdf (accessed on 3 January 2019).

17. Colmenar-Santos, A.; Campíñez-Romero, S.; Pérez-Molina, C.; Mur-Pérez, F. An assessment of photovoltaic potential in shopping centres. Sol. Energy 2016, 135, 662-673. [CrossRef]

18. Hills, C.D.; Tripathi, N.; Carey, P.J. Mineralization Technology for Carbon Capture, Utilization, and Storage. Front. Energy Res. 2020, 8. [CrossRef]

19. Romanov, V.; Soong, Y.; Carney, C.; Rush, G.E.; Nielsen, B.; O'Connor, W. Mineralization of Carbon Dioxide: A Literature Review. ChemBioEng Rev. 2015, 2, 231-256. [CrossRef] 